Kiều Đình Hùng (2010) có mức tốt 79,2\%, trung bình 18,8\%, xấu 2,0\%; Nguyễn Hiền Nhân (2019) có mức tốt $69,2 \%$, khá và trung bình $30,8 \%$ [4].

\section{KẾT LUẬN}

Hiện nay xu hướng điều trị HOSTLC là can thiệp tối thiểu giải phóng chèn ép. Tuy vậy, phẫu thuật giải phóng chèn ép, hàn xương liên thân đốt và cố định bằng nẹp vít qua cuống lối sau vẫn là phương pháp kinh điển trong điều trị HOSTLC và hiện tại đang được áp dụng phổ biến tại nhiều cơ sở kết quả điều trị tốt đạt $76,8 \% \%$, tỷ lệ biến chứng sau mổ thấp và không có tử vong sau mổ.

\section{TÀI LIÊU THAM KHẢO}

1. Lê Văn Công, Phạm Trịnh Quốc Khanh, Nguyển Văn Lâm (2018), Kết quả điều trị hep ống sống thắt lưng-cùng do thoái hóa bằng phẫu thuật giải ép kết hợp hàn xương liên thân sống tại
Bệnh viện quân Y 121 năm 2016-2017, Bệnh viện quân Y 121, TP Cần Thơ.

2. Hoàng Gia Du (2018), "Đánh giá kết quả điều trị trượt đốt sống thắt lưng L4L5 bắng phẫu thuật lấy đĩa đệm, cố định cột sông và ghép xương liên thân đốt". Tạp trí Y học Việt Nam, 465(2), tr.30-35.

3. Vũ Minh Hải (2016), "Kết quả điều trị phẫu thuật hẹp ống sông thắt lưng tại bệnh viện Đại học Y Thái Bình". Y họ Việt Nam, 2, tr.143-147.

4. Nguyến Hiền Nhân, Nguyê̂n Tuấn Tài, Trinh Quốc Minh, et al (2019). "Đánh giá sau phâuu thuật hẹp ống sống thắt lưng đa tầng do thoái hóa bằng phương pháp hàn xương liên thân đốt lối sau tại bệnh viện Trưng Vương". Y học TP Hồ Chí Minh, 23 (6), tr.28-33.

5. Nguyễn Vũ (2015), Nghiên cứu điều trị trượt đốt sông thắt lưng bằng phương pháp cố định cột sống thắt lưng qua cuống kết hợp hàn xưởng liển thân đốt, Luận văn tiến sỹ, Đại học Y Hà Nội.

6. Farrokhi M. R., Yadollahikhales G., Gholami M. (2018), "Clinical Outcomes of Posterolateral Fusion Versus Posterior Lumbar Interbody Fusion in Patients with Lumbar Spinal Stenosis and Degenerative Instability", Pain Physician, 21 (4), pp. $383-40$

\title{
ĐÁNH GIÁ TÍNH AN TOÀN VÀ HIÊUU QUẢ CỦA VIÊN TRĨ THIÊN DƯỢC TRÊN BÊNH NHÂN TRĨ் Nô̂I Độ II CÓ CHẢY MÁU THEO CÁC THỂ BÊ̂NH Y HỌC CỔ TRUYỀN
}

\section{Lê Thị Minh Phương1, Lê Mạnh Cường², Phạm Đức Huấn ${ }^{1}$, Phạm Bá Tuyến ${ }^{3}$}

\section{TÓM TẮT}

Muc tiêu: Đánh giá tính an toàn và hiệu quả của viên Trĩ Thiên Dược trên các bệnh nhân trĩ nội độ II có chảy máutheo các thể bệnh $Y$ học cổ truyền. Đối tượng và phương pháp: Phân tích gộp dựa trên dữ liệu bệnh nhântừ 2 thử nghiệm lâm sàng giai đoạn II và III ngâuu nhiên, mù đôi, có đối chứng. Kết quả: Viên Trĩ Thiên Dược an toàn và có tác dụng làm giảm rõ rệt các triệu chứng như đau rát hậu môn, đại tiên ra máu, xung huyết búi trĩ trên bệnh nhân nghiển cứu ở cả 3 thể bênh là thể huyết ứ, thấp nhiêt và khí huyết hư, trong đó, hiệu quả rõ rệt nhất trên thể thấp nhiêt. Kết luân: Viên Trĩ Thiên Dược có tác dung điều trị bệnhtrĩ nộ̉i độ II có chảy máu trên các thể lâm sàng $\mathrm{YHCT}$. Dược.

Từ khóa: Trĩ nội độ II có chảy máu, viên Trĩ Thiên

\footnotetext{
${ }^{1}$ Trường Đại học Y Hà Nội

²Bệnh viện Y học cổ truyền Trung Ương,

${ }^{3}$ Bệnh viện Y học cổ truyền Bộ Công An

Chịu trách nhiệm chính: Lê Mạnh Cường;

Email: drcuong68@gmail.com

Ngày nhận bài: 4/11/2021

Ngày phản biện khoa học: 30/11/2021

Ngày duyệt bài: 21/12/2021
}

\section{SUMMARY \\ EVALUATING THE SAFETY AND EFFICACY OF TRI THIEN DUOC CAPSULE IN THE TREATMENT OF BLEEDING STAGE II INTERNAL HEMORRHOIDS ACCORDING TO TRADITIONAL MEDICAL SYNDROMES}

Objectives: To evaluate the safety and efficacy of Tri ThienDuoc capsule in the treatment of bleeding stage II internal hemorrhoids according to traditional medical syndromes. Subjects and method: Metaanalysis of individual patient data from 2 randomized, double-blind, placebo-controlled, phase II and III clinical trials. Results: Tri ThienDuoc was safe and reduced symptoms such as anal itching, rectal bleeding, and thrombosed hemorrhoids in patients with three syndromes, including blood stasis, dampheat, and a deficiency of qi and blood, whose most pronounced effect was on the damp-heat syndrome. Conclusion: Tri ThienDuoc was effective in reducing symptoms of Bleeding stage II internal hemorrhoids according to traditional medical syndromes.

Key words: Bleeding stage II internal hemorrhoids, Tri ThienDuoc.

\section{I. ĐẶT VẤN ĐỀ}

Trĩ nội là bệnh lý vùng hậu môn trực tràng phổ biến, có tỉ lệ mắc cao trên $55 \%$ dân số nước 
ta và ảnh hưởng nhiều đến chất lượng cuộc sống của người bệnh $[1,2]$. Trĩ nội được xếp vào chứng Hạ Trĩ của $Y$ học cổ truyền (YHCT). Nguyên nhân là do phong, táo, thấp, nhiệt kết hợp lại mà gây bệnh, được chia thành các thể huyết ứ, thấp nhiệt và khí huyết hư $[3,4]$. Viên Trĩ Thiên Dược với thành phần chính từ rau sam (Portulaca Öleracea L.) và rau dên gai (Amaranthus spinosus L.) là hai vị thuốc quen thuộc trong dân gian, đã được sử dụng để điều trị Hạ trĩ và đem lại hiệu quả nhất định. Viên Trĩ Thiên Dược đã được nghiên cứu thử nghiệm lâm sàng giai đoạn II và III cho thấy có tính an toàn và hiệu quả điều trị rõ rệt trên bệnh nhân trĩ nội độ II có chảy máu, tương đương với thuốc có chứa hoat chất Diosmin [5-7]. Tuy nhiên các nghiên cứu trên chỉ tập trung đánh giá trên các tiêu chí triệu chứng theo $\mathrm{Y}$ học hiện đại (YHHĐ) mà chưa đánh giá hiệu quả theo khía canh YHCT. Để đánh giá hiệu quả của viên Trĩ Thiên Dược trên các thể bênh YHCT, nghiên cứu được thực hiện với mục tiêuđánh giá tính an toàn và hiệu quả của viên Trĩ Thiên Dược trên các bệnh nhân trĩ nôi độ II có chảy máu theo các thể bệnh Y học cổ truyền.

\section{II. ĐỐI TƯỢNG VÀ PHƯƠNG PHÁP NGHIÊN CỨU}

2.1. Đối tượng nghiên cứu: dữ liệu bệnh nhân từ 2 thử nghiệm lâm sàng giai đoạn II và III ngẫu nhiên, mù đôi, có đối chứng đánh giá tác dụng của viên Trĩ Thiên Dược trên bệnh nhân trĩ nội độ II có chảy máu tại Bệnh viện Đại học Y Hà Nội, Bệnh viện $Y$ học cổ truyền Trung ướng, Bệnh viện $Y$ học cổ truyền Bộ Công an, từ tháng 3/2019 đến tháng 11/2020.

\section{- Tiêu chuẩn lựa chon:}

$\checkmark$ Bênh nhân nam hoắc nữ, tuổi từ $18-65$.

$\checkmark$ Được chẩn đoán trĩ nội độ II có chảy máu theo tiêu chuẩn của Hội Tiêu hóa Hoa Kỳ.

$\checkmark$ Được điều trị bẳng viên Trĩ Thiên Dược tối thiểu 14 ngày.

$\checkmark$ Đồng ý tham gia và tuân thủ các yêu cầu của nghiên cứu.

$\checkmark$ Có đủ dữ liệu lâm sàng và soi hậu môn trực tràng ống cứng sau 14 ngày điều trị.

\section{- Tiêu chuẩn loai trừ:}

$\checkmark$ Ung thư đại tràng và các ung thư khác đã được phát hiện.

$\checkmark$ Có bênh lý hâu môn trực tràng như viêm ống hậu môn, nút kẽ hậu môn có chảy máu.

$\checkmark$ Mắc các bệnh lý toàn thân, bệnh lý cấp tính hoăc man tính khác.

$\checkmark$ Trĩ hô̂n hợp, hoăc tình trang phải đòi hỏi can thiệp phẫu thuật ngay như tụ máu, chảy máu nặng hoặc nhồi máu trĩ.

$\checkmark$ Mới dùng thuốc điều trị trĩ khác dưới 07 ngày.

$\checkmark$ Dị ứng với các thành phần của thuốc.

$\checkmark$ Phu nữ có thai, đang cho con bú.

- Thuốc nghiên cứu: Viên Trĩ Thiên Dược $650 \mathrm{mg}$ sản xuất tại Công ty Cổ phần Dược phẩm Thiên Dược, đạt tiêu chuẩn cơ sở.

2.2. Phương pháp nghiên cứu. Phương pháp phân tích gộp dữ liệu 114 bệnh nhân (Individual Patient Data Meta-analysis)đạt tiêu chuẩn lựa chọn của nghiên cứu được khám và phân vào 3 nhóm theo 3 thể bệnh của $\mathrm{Ha}$ trĩ theo YHCT từ 2 thử nghiêm lâm sàng giai đoạn II và III ngẫu nhiên, mù đôi, có đối chứng.

\subsection{Các chỉ tiêu nghiên cứu}

- Đăc điểm bênh nhân: Tỷ lệ giới, tuổi trung bình, thời gian phát hiện bệnh, yếu tố nguy co

\section{Dướ:}

+ Mức độ đại tiên ra máu (không, chảy máu nhẹ: máu bám phân hoặc dính giấy vệ sinh, chảy máu vừa: máu nhỏ giọt, chảy máu nặng: máu phun thành tia).

+ Mức độ đau hậu môn khi đại tiện theo thang điểm VAS (nặng: $6<$ VAS $\leq 10$, vừa: $3<$ VAS $\leq 6$, nhẹ: $0<$ VAS $\leq 3$, không đau, VAS $=0$ ).

+ Mức độ rối loạn đại tiện qua thang điểm Wexner (nặng: 21-30 điểm, vừa: 11-20 điểm, nhẹ: 6-10 điểm, không rối loạn đại tiện: 0-5 điểm).

+ Mức đô sung huyết búi trĩ qua soi hậu môn - trực tràng bằng ống cứng (bình thường, xung huyết nhẹ: có vài điểm xung huyết nhỏ, xung huyết trung bình: phần lớn xung huyết đỏ, xung huyết nặng: xung huyết đỏ, có chảy máu).

- Theo dõi các tác dụng không mong muốn: Các tác dụng không mong muốn trên lâm sàng được phân tích theo các thể lâm sàng YHCT.

2.4. Xử lý số liệu. Phương pháp thống kê y sinh hoc. Sử dunng phần mềm SPSS 20.0.

2.5. Đạo đức trong nghiên cứu. Dữ liệu nghiên cứu được thu thập từ 2 nghiên cứu thử nghiệm lâm đã được sự chấp thuận cho phép triển khai của Hội đồng đạo đức trong nghiên cứu y sinh học quốc gia theo quyết định số 460/QĐ-BYT và số 7201/QĐ-BYT.

\section{KẾT QUẢ NGHIÊN CứU}

Từ dữ liệu thu được 114 bênh nhân trĩ nội độ II có chảy máu thuộc 3 thể bênh YHCT gồm 65 bệnh nhân thể huyết ứ, 39 bệnh nhân thể thấp nhiệt, 10 bệnh nhân thể khí huyết hư.Trong đó, tỉ lể nữ/nam là 1,07 , tuổi trung bình là $36,25 \pm$ 12,68 tuổi, thời gian mắc bệnh trên 2 năm chiếm 
tỉ lệ cao nhất là 65,8\%.

3.1. Tác dụng điều trị của viên Trĩ Thiên Dược theo các thể bệnh YHCT trên bệnh nhần trĩ nội độ II có chảy máu
3.1.1. Tác dụng câm máu sau điêu trị. Ở thời điểm trước và sau điều trị không có sự khác biệt về mức độ chảy máu giữa 3 thể bệnh $(p>0,05)$, có sự cải thiện mức độ chảy máu ở cả 3 thể bệnh so với trước điều trị $(p<0,05)$.

Bảng 3.1. Mức độ chảy máu trước và sau điều trị

\begin{tabular}{|c|c|c|c|c|c|c|}
\hline \multirow{2}{*}{ Thể bệnh } & \multirow{2}{*}{$\begin{array}{l}\text { Mức độ } \\
\text { chảy máu }\end{array}$} & \multicolumn{2}{|c|}{ Trước điều trị } & \multicolumn{2}{|c|}{ Sau điêu trị } & \multirow[b]{2}{*}{$\mathbf{p}$} \\
\hline & & $\mathbf{n}$ & $\%$ & $\mathbf{n}$ & $\%$ & \\
\hline \multirow{4}{*}{$\begin{array}{l}\text { Huyết ứ } \\
(n=65)\end{array}$} & Không & 0 & 0 & 36 & 55,4 & \multirow{4}{*}{$<0,05$} \\
\hline & Nhe & 38 & 69 & 29 & 44,6 & \\
\hline & Vừa & 15 & 27 & 0 & 0 & \\
\hline & Nặng & 2 & 4 & 0 & 0 & \\
\hline \multirow{4}{*}{$\begin{array}{l}\text { Thấpnhiệt } \\
(\mathrm{n}=39)\end{array}$} & Không & 0 & 0 & 34 & 87,2 & \multirow{4}{*}{$<0,05$} \\
\hline & Nhe & 16 & 37,2 & 4 & 10,3 & \\
\hline & Vừa & 25 & 58,1 & 1 & 2,5 & \\
\hline & Nặng & 2 & 4,7 & 0 & 0 & \\
\hline \multirow{4}{*}{$\begin{array}{l}\text { Khí huyết hư } \\
\qquad(n=10)\end{array}$} & Không & 0 & 0 & 5 & 50 & \multirow{4}{*}{$<0,05$} \\
\hline & Nhe & 5 & 50 & 4 & 40 & \\
\hline & Vứa & 4 & 40 & 1 & 10 & \\
\hline & Nặng & 1 & 10 & 0 & 0 & \\
\hline & & \multicolumn{2}{|c|}{$>0,05$} & \multicolumn{2}{|c|}{$>0,05$} & \\
\hline
\end{tabular}

3.1.2. Đánh giá hiệu quả giảm đau tức hậu môn khi đi đại tiện

Bảng 3.2. Mức độ đau khi đại tiện theo thang điểm VAS-10 trước và sau điều trị

\begin{tabular}{|c|c|c|c|c|c|c|}
\hline \multirow{2}{*}{ Thể bệnh } & \multirow{2}{*}{$\begin{array}{c}\text { Mức độ } \\
\text { đau }\end{array}$} & \multicolumn{2}{|c|}{ Trước điêuu trị } & \multicolumn{2}{|c|}{ Sau điêuu trị } & \multirow[b]{2}{*}{$\mathbf{p}$} \\
\hline & & $\mathbf{n}$ & $\%$ & $\mathbf{n}$ & $\%$ & \\
\hline \multirow{4}{*}{$\begin{array}{l}\text { Huyết ứ } \\
(\mathrm{n}=65)\end{array}$} & Không (0 điểm) & 13 & 20 & 46 & 70,8 & \multirow{4}{*}{$<0,05$} \\
\hline & Nhẹ (1-3 điểm) & 24 & 36,9 & 6 & 9,2 & \\
\hline & Vừa (4-6 điếm) & 25 & 38,5 & 13 & 20 & \\
\hline & Nặng (7-10 điếm) & 3 & 4,6 & 0 & 0 & \\
\hline \multirow{4}{*}{$\begin{array}{l}\text { Thấp nhiệt } \\
(n=39)\end{array}$} & Khồng (0 điếm) & 8 & 20,5 & 25 & 64,1 & \multirow{4}{*}{$<0,05$} \\
\hline & Nhẹ (1-3 điếm) & 15 & 38,3 & 4 & 10,3 & \\
\hline & Vừa (4-6 điếm) & 16 & 41,0 & 10 & 25,6 & \\
\hline & Nặng (7-10 điếm) & 0 & 0 & 0 & 0 & \\
\hline \multirow{4}{*}{$\begin{array}{l}\text { Khí huyết hư } \\
\quad(n=10)\end{array}$} & Khô̂ng (0 điếm) & 2 & 20 & 7 & 70 & \multirow{4}{*}{$<0,05$} \\
\hline & Nhẹ (1-3 điểm) & 4 & 40 & 0 & 0 & \\
\hline & Vừa (4-6 điểm) & 4 & 40 & 3 & 30 & \\
\hline & Nặng (7-10 điếm) & 0 & 0 & 0 & 0 & \\
\hline & p & \multicolumn{2}{|c|}{$>0,05$} & \multicolumn{2}{|c|}{$>0,05$} & \\
\hline
\end{tabular}

Ở thời điểm trước và sau điều trị đều không có sự khác biệt về mức độ đau khi đại tiện giữa 3 thể bệnh $(p>0,05)$, có sực cải thiện mức độ đau ở cả 3 nhóm so với trước điều trị $(p<0,05)$

3.1.3. Đánh giá tình trạng xung huyết búi trĩ sau điêu trị

Bảng 3.3. Mức độ xung huyết búi trĩ trước và sau điều trị

\begin{tabular}{|c|c|c|c|c|c|c|}
\hline \multirow{2}{*}{ Thể bệnh } & \multirow{2}{*}{$\begin{array}{c}\text { Mức độ } \\
\text { Xung huyết }\end{array}$} & \multicolumn{2}{|c|}{ Trước điều trị } & \multicolumn{2}{|c|}{ Sau điều trị } & \multirow[b]{2}{*}{$\mathbf{p}$} \\
\hline & & n & $\%$ & $\mathbf{n}$ & $\%$ & \\
\hline \multirow{4}{*}{$\begin{array}{l}\text { Huyết ứ } \\
(n=65)\end{array}$} & Không & 1 & 1,5 & 33 & 50,8 & \multirow{4}{*}{$<0,05$} \\
\hline & Nhe & 34 & 52,3 & 27 & 41,5 & \\
\hline & Vừa & 27 & 41,5 & 5 & 7,7 & \\
\hline & Nặng & 3 & 4,6 & 0 & 0 & \\
\hline \multirow{4}{*}{$\begin{array}{l}\text { Thấpnhiệt } \\
(n=39)\end{array}$} & Không & 3 & 7,7 & 29 & 74,4 & \multirow{4}{*}{$<0,05$} \\
\hline & Nhe & 20 & 51,3 & 9 & 23,1 & \\
\hline & Vừa & 16 & 41,0 & 1 & 2,5 & \\
\hline & Nặng & 0 & 0 & 0 & 0 & \\
\hline \multirow{2}{*}{$\begin{array}{l}\text { Khí huyết hư } \\
(n=10)\end{array}$} & Không & 0 & 0 & 3 & 30 & \multirow{2}{*}{$<0,05$} \\
\hline & Nhe & 6 & 60 & 6 & 60 & \\
\hline
\end{tabular}


VIETNAM MEDICAL JOURNAL N01 - JANUARY - 2022

\begin{tabular}{|c|c|c|c|c|c|c|}
\hline & Vư̆a & 2 & 20 & 1 & 10 & 0 \\
\cline { 2 - 7 } & & 2 & 20 & 0 & 0 \\
\hline
\end{tabular}

Sau điều trị tình trạng xung huyết búi trĩ ở cả 3 nhóm đều giảm so với trước điều trị $(p<0,05)$, trong đó tỉ lệ cải thiện tốt nhất ở nhóm thấp nhiệt và huyết ứ.

3.1.4. Đánh giá mức độ rối loạn đại tiện sau điêuu trị

Bảng 3.4. Mức độ rôi loạn đại tiện theo thang điểm Wexner trước và sau điêu trị

\begin{tabular}{|c|c|c|c|c|c|c|}
\hline \multirow{2}{*}{ Thể bệnh } & \multirow{2}{*}{ Rối loạn đại tiện } & \multicolumn{2}{|c|}{ Trước đîêu tri } & \multicolumn{2}{|c|}{ Sau đîêu trị } & \multirow[b]{2}{*}{$\mathbf{p}$} \\
\hline & & $\mathbf{n}$ & $\%$ & $n$ & $\%$ & \\
\hline \multirow{4}{*}{$\begin{array}{l}\text { Huyết ứ } \\
(n=65)\end{array}$} & Không & 45 & 69,2 & 54 & 83,1 & \multirow{4}{*}{$<0,05$} \\
\hline & Nhe & 13 & 20,0 & 11 & 16,9 & \\
\hline & Vừa & 7 & 10,8 & 0 & 0 & \\
\hline & Nặng & 0 & 0 & 0 & 0 & \\
\hline \multirow{4}{*}{$\begin{array}{c}\text { Thấpnhiệt } \\
(n=39)\end{array}$} & Không & 22 & 56,4 & 30 & 76,9 & \multirow{4}{*}{$>0,05$} \\
\hline & Nhe & 16 & 41,0 & 7 & 17,9 & \\
\hline & Vừa & 1 & 2,6 & 2 & 5,1 & \\
\hline & Nặng & 0 & 0 & 0 & 0 & \\
\hline \multirow{4}{*}{$\begin{array}{l}\text { Khí huyết hư } \\
\quad(n=10)\end{array}$} & Không & 5 & 50 & 8 & 80 & \multirow{4}{*}{$<0,05$} \\
\hline & Nhe & 2 & 20 & 2 & 20 & \\
\hline & Vừa & 3 & 30 & 0 & 0 & \\
\hline & Nặng & 0 & 0 & 0 & 0 & \\
\hline \multicolumn{2}{|r|}{$p$} & \multicolumn{2}{|c|}{$>0,05$} & \multicolumn{2}{|c|}{$>0,05$} & \\
\hline
\end{tabular}

Sau điều trị không mức độ rối loạn đại tiên giữa 3 nhóm đều giảm $(p<0,05)$, nhưng không có sự khác biệt giữa 3 thể bệnh ( $p>0,05)$.

3.1.6. Mối tương quan giứa thể lâm sàng và kết quả cải thiện các chỉ tiêu nghiên cứu

Bảng 3.5. Mô hình hồi quy logistic thể bệnh YHCT và các chỉ số có cải thiện sau điều trị

\begin{tabular}{|c|c|c|c|}
\hline Các chỉ số & Huyết ứ $(\mathbf{n = 6 5})$ & Thấp nhiệt $(\mathbf{n = 3 9})$ & Khí huyết hư $(\mathbf{n = 1 0})$ \\
\hline Ngưng đại tiện ra máu & 0,242 & 0,390 & 0,999 \\
\hline Giảm đau & 0,000 & 0,003 & 0,998 \\
\hline Rối loạn đại tiện & 0,813 & 0,239 & 0,999 \\
\hline Mức độ xung huyết & 0,731 & 0,108 & 0,998 \\
\hline Độ sa trĩ & 0,168 & 0,963 & - \\
\hline -2Log likelihood & 43,833 & 27,225 & - \\
\hline
\end{tabular}

Giá trị -2Log likelihood của mô hình thể khí thấp nhiệt là nhỏ nhất, tiếp theo là mô hình thể huyết ứ. Riêng với thể khí huyết hư không tính đượcgiá trị -2Log likelihood do số lượng bệnh nhân ít (0 bệnh nhân).

3.2. Đánh giá tác dụng không mong muốn của viên Trĩ Thiên Dược theo thể bệnh YHCT trên bệnh nhân trĩ nội độ II có chảy máu

3.2.1. Tác dụng không mong muốn trên lâm sàng

Bảng 3.6. Tác dung không mong muốn trên lâm sàng

\begin{tabular}{|c|c|c|c|c|c|c|}
\hline \multirow{2}{*}{ Triệu chứng Thế bệnh } & \multicolumn{2}{|c|}{ Huyết ứ $(n=65)$} & \multicolumn{2}{|c|}{ Thấp nhiệt $(n=39)$} & \multicolumn{2}{|c|}{ Khí huyết hư (n=10) } \\
\hline & $\mathbf{n}$ & $\%$ & $\mathrm{n}$ & $\%$ & $\mathbf{n}$ & $\%$ \\
\hline Mệt mỏi & 1 & 1,5 & 2 & 5,1 & 2 & 20 \\
\hline Buồn nôn & 2 & 3 & 1 & 2,5 & 0 & 0 \\
\hline Ợ hơi, nóng rát thượng vị & 2 & 3 & 0 & 0 & 0 & 0 \\
\hline
\end{tabular}

Bệnh nhân thể huyết ứ được ghi nhận có biểu hiện mệt mỏi $(1,5 \%)$, buồn nôn $(3 \%)$, ợhơi, nóng rát thượng vị (3\%). Ở bệnh nhân thể thấp nhiệt ghi nhận có biểu hiện mệt mỏi $(5,1 \%)$, buồn nôn $(2,5 \%)$. Bệnh nhân thể khí huyết hư có biểu hiện mệt mỏi (20\%).

3.2.2. Tác dụng không mong muốn trên cận lâm sàng. Các nghiên cứu thữ nghiệm lâm sàng giai đoạn II, III không ghi nhận tác dụng không mong muốn của thuốc qua những thay đổi giá trị huyết học, các thông số sinh hóa, kết quả đông máu và kết quả phân tích nước tiểu.

\section{BÀN LUÂN}

Viên Trĩ Thiên Dược với thành phân chính từ rau sam (Portulaca Oleracea L.) và rau dền gai (Amaranthus spinosus L.), là 2 vị thuốc có tác dụng thanh nhiệt trừ thấp, đã được sử dụng 
trong YHCT để điều trị bệnh trĩ. Kết quả nghiên cứu phân tích gộp dựa trên dữ liệu bệnh nhân từ 2 thử nghiệm lâm sàng ngẫu nhiển đánh giá hiệu quả điều trị của viên Trĩ Thiên Dược trên 114 bệnh nhân trĩ nội độ II có chảy máu thuộc 3 thể bệnh YHCT gồm 65 bệnh nhân thể huyết ứ, 39 bệnh nhân thể thấp nhiệt, 10 bệnh nhân thể khí huyết hư với tỉ lệ nữ/nam là 1,07 , tuổi trung bình là $36,25 \pm 12,68$ tuổi, thời gian mắc bệnh trên 2 năm chiếm tỉ lệ cao nhất là $65,8 \%$ cho thấy viên Trĩ Thiên Dược có hiệu quả điều trị rõ rệt lên một số triệu chứng chính của bệnh trĩ ở cả 3 thể bệnh YHCT.

Chảy máu và đau khi đại tiện hai triệu chứng chính khiến người bệnh trĩ phải đi khám [8]. Kết quả cho thấy ở bệnh nhân được điều trị bằng Trĩ Thiên Dược, tỉ lệ bệnh nhân ngừng chảy máu sau điều trị đều tăng lần lượt là $55,4 \%$ ở thể huyết ứ, $87,2 \%$ ở thể thấp nhiệt, 50\% ở thể khí huyết hư và không còn bênh nhân chảy máu ở mức độ nặng với $p<0,05$ (Bảng 3.1). Mức độ đau của các bệnh nhân đều có giảm $(p<0,05)$ với tỉ lệ bệnh nhân đau nhe và vừa ở 3 thể huyết ứ, thấp nhiệt, khí huyết hư lần lượt giảm còn $29,2 \%, 35,9 \%$ và $30 \%$ (Bảng 3.2). Bên cạnh đó, mức độ xung huyết búi trĩ ở cả 3 thể bệnh đều giảm $(p<0,05)$ với tỉ lệ bệnh nhân khổng còn xung huyết là $50,8 \%$ ở thể huyết ứ, $74,4 \%$ ở thể thấp nhiệt và $30 \%$ ở thể khí huyết hư, không còn bệnh nhân nào ở mức xung huyết nặng sau điều trị (Bảng 3.4). Tình trang rối loan đại tiện có xu hướng cải thiện rõ rệtở thể huyết ứ và khí huyết hư $(p<0,05)$ với tỉ lệ không rối loạn đại tiện sau điêu trị lần lượt là $83,1 \%$ và $80 \%$, cải thiện tốt ở thể thấp nhiệt với tî lệ không rối loạn đai tiên sau điều trị là $76,9 \%$ (Bảng 3.5). Dưa vào đánh giá mối tương quan giữa thể lâm sàng và kết quả cải thiện của các chỉ tiêu nghiên cứu, ta thấyviên Trĩ Thiên Dược có xu hướng cho kết quả tốt trên thể thấp nhiệt sau đó đến thể huyết ứ (Bảng 3.6). Kết quả này tương đồng với nghiên cứu trước đó của Mai An Vân (2019) có tỉ lệ bệnh nhân giảm chảy máu và giảm đau hậu môn sau sử dụng viên Trĩ Thiên Dược lần lượt là $83,3 \%$ và $66,6 \%$, nghiên cứu cũng không ghi nhận bệnh nhân xung huyết búi trĩ nặng sau điều trị [6]. Giải thích cho kết quả trên do viên Trĩ Thiên Dược gồm 2 thành phần chính là rau sam và rau dền gai. Rau sam vị chua, tính hàn, có tác dụng thanh nhiệt giải độc, lương huyết chỉ huyết; rau dền gai vị ngott, tính hơi hàn, có tác dụng thanh nhiệt, thu liếm chỉ tả nên giúp làm co mạch, giảm chảy máu, giúp săn se, giảm sưng nề, nên có hiệu quả cầm máu tốt, ngoài ra còn được chứng minh có tác dụng kháng viêm hiệu quả trên cơ trơn ruột trong mô hình gây viểm thực nghiệm nên giúp giảm đau, giảm sưng nề búi trĩ. Trong thành phân rau sam chứa nhiều chất nhây cùng nhiều loại axit hữu cơ giúp nhuận tràng, thông tiện, trị nóng trong làm giảm táo bón. Rau dền gai có hàm lượng chất xơ cao cũng góp phần cải thiện tình trạng táo bón, qua đó cải thiện tình trạng rối loạn đại tiện của bệnh nhân.

Các kết quả báo cáo thử nghiệm lâm sàng giai đoạn II và III đánh giá hiệu quả của viên Trĩ Thiên Dược trên bệnh nhân trĩ் nội độ II có chảy máu không ghi nhận tác dụng không mong muốn nào trên chức năng tạo máu, chức năng gan, chức năng lọc của thận qua các xét nghiệm cận lâm sàng. Tuy nhiên có ghi nhận một số bềnh nhân gặp các tác dụng không mong muốn như ợ hơi, nóng rát thượng vị, buồn nôn và mệt mỏi. Trong đó bệnh nhẩn thể huyết ứ được ghi nhận có biểu hiện mệt mỏi $(1,5 \%)$, buồn nôn (3\%), ợ hơi, nóng rát thượng vị (3\%). Ở bệnh nhân thể thấp nhiệt ghi nhận có biểu hiện mệt mỏi $(5,1 \%)$, buồn nôn $(2,5 \%)$. Bệnh nhân thể khí huyết hư có biểu hiện mệt mỏi (20\%) (Bảng 3.6) Các triệu chứng xuất hiện khi uống thuốc trước bữa ăn, xuất hiện trong thời gian ngắn là 1 ngày và đều ở mức độ nhẹ, không gây ảnh hưởng đến các hoạt động chức năng hay xã hội của bệnh nhân.

\section{KẾT LUÂN}

Viên Trĩ Thiên Dược có tác dụng điều trị trên các thể lâm sàng YHCT là thể huyết ứ, thấp nhiệt và khí huyết hư, trong đó tác dụng rõ rệt nhất trên thể thấp nhiệt thông qua: giảm mức độ chảy máu khi đi đại tiện, giảm mức độ đau hậu môn khi đại tiện, giảm xung huyết búi, giảm mức độ rối loạn đại tiện theo thang điểm Wexner. Viên Trĩ Thiên Dược không gây tác dụng không mong muốn đáng kể trên bệnh nhân trĩ nội độ II có chảy máu.

\section{TÀI LIÊU THAM KHẢO}

1. Lohsiriwat V.Hemorrhoids: From basic pathophysiology to clinical management, World journal of gastroenterology. 2012, 18(17), doi:10,3748/wjg.v18.i17.

2. Nguyển Mạnh Nhâm, Nguyễn Đình Chì (1999), Tình hình bệnh trĩ ở một nhà máy (qua điều tra dịch tễ học và̀ kết quả bước đầu của công tác điêu trị). Tạp chí Ngoại khoa, 4, 15-21.

3. Hải Thượng Lãn Ông, HảiThượng $Y$ tông tâm lĩnh, Hành giản trân nhu, Quyển 50̉, NXB Y học.

4. Trường Đại học $Y$ HàNội - Khoa $Y$ học cổ truyền (2007), Trĩ, Ngoại khoa $Y$ học cổ truyên, Nhà xuất bản $Y$ học, 77-80.

5. "Nghiên cứu tính an toàn của viên "Trĩ Thiên Dược" trên thử nghiệm lâm sàng giai đoạn I", Tạp 
chí Y Dược học cổ truyền Quân sự, 9 (2), 14 - 20.

6. Mai An Vân (2019), Đánh giá tác dung của viên nang cứng từ rau sam ((Portulaca Oleracea L.), rau dền gai (Amaranthus Spinosus L.) trong điêu trị bệnh trĩ nội độ II chảy máu, Luận văn Thạc sĩ Y học, Trường Đai học Y Hà Nội.

7. Phạm Đức Hiuấn và cộngsự (2021), Nghiên cứu thử nghiệm lâm sàng giai đoạn III, đa trung tâm, ngẫu nhiên, nhãn mở, nhóm đối chứng song song, đánh giá hiêu quả và an toàn của viên Trĩ Thiển Dược trên bệnh nhân trĩ nội độ II chảy máu so sánh với thuốc có hoạt chất Diosmin ,Báo cáo đề tài cấp Bô Y tế.

8. Trường Đại học $Y$ Hà Nội - Bộ môn Ngoại (2006), Băi giảng Bênh học Ngoại khoa tâp Iİ, Nhà xuất bản Y học, Hà Nội, 67-68.

\section{ĐĂC ĐIỂM LÂM SÀNG, CÂN LÂM SÀNG VÀ KẾT QUẢ ĐIỀU TRI TRUYỀN MÁU TRỀN BÊNH NHÂN THALASSEMIA TẠI BỆNH VIỆN TRUNG ƯO'NG THÁI NGUYÊN}

\section{TÓM TẮT}

Muc tiêu: Mô tả đặc điểm lâm sàng, cận lâm sàng và kểt quả điều trị truyền máu ở bệnh nhân bị thalassemia. Đối tượng và phương pháp: 53 bệnh nhân thalassemia đang điều trị tại Bệnh viện Trung ương Thái Nguyên từ tháng 6/2020 đến tháng 9/2021. Mô tả cắt ngang. Kết quả: $100 \%$ bệnh nhân có tình trạng quả tải sắt trong đó quá tải sắt mức độ nặng chiếm $67,9 \%$. Bệnh nhân có tình trạng lách to và đã cắt lách chiếm tỷ lệ $83 \%$, trong đó tỳ lệ bệnh nhân có lách to độ I - II là cao nhất (50,9\%). Tình trang gan to chiếm $74,4 \%$, sạm da chiếm $58,5 \%$; vàng da chiếm $86,8 \%$. Nồng độ Hỉ lúc nhập viện trung bình là: 65,91 $\pm 12,33 \mathrm{~g} / \mathrm{l} .20,8 \%$ bệnh nhân có kêt quả xét nghiệm Coombs dương tính. Khoảng cách giữa hai lần truyền máu liên tiếp của bệnh nhân nhóm nghiên cứu trung bình là 4,82 $\pm 1,26$ tuần. Thể tích khối hồng cầu (KHC) truyền trong 1 đợt điều trị trung bình là 477,36 $\pm 179,36 \mathrm{ml}$. Nồng độ $\mathrm{Hb}$ lúc ra viện trung bình là $102,13 \pm 10,45 \mathrm{~g} / \mathrm{l}$. Mức tăng nồng độ $\mathrm{Hb}$ trung bình là $36,83 \pm 13,84 \mathrm{~g} / \mathrm{l}$. Nhu câu truyên máu/năm trung bình là $251,58 \pm 113,05 \mathrm{ml} / \mathrm{kg} / \mathrm{năm}$. Tốc độ giảm nồng đô $\mathrm{Hb}$ theo tuần trung bình là $5,25 \pm 3,54 \mathrm{~g} / \mathrm{l} / \mathrm{tuâan}$. Kết luận: Bênh nhân đều có một sỗ đặc điểm lâm sàng như: tình trạng gan to, sạm da, vàng da, lách to. Nông độ $\mathrm{Hb}$ lúc nhập viện trung bình là rất thấp $(65,91 \pm 12,33 \mathrm{~g} / \mathrm{l}) ; 20,8 \%$ bệnh nhân có kết quả xét nghiệm Coombs dương tính. Nhu cầu truyền máu của các beênh nhân theo năm rất cao $(251,58 \pm 113,05$ $\mathrm{ml} / \mathrm{kg} / \mathrm{năm})$. Tỷ lệ bệnh nhân có tình trạng quá tải sắt mức độ nặng chiếm $67,9 \%$, đối tượng này cần được thảisắt tích cực và theo dõi các biến chứng.

Từ khóa: Thalassemia, hemoglobin, truyền máu, quá tải sắt

\section{SUMMARY}

\section{THE CLINICAL, LABORATORY AND TREATMENT}

*Bênh viện Trung ương Thái Nguyên

**Trường Đai học Y Dược Thái Nguyên

Chịu trách nhiệm chính: Lê Thùy Dung

Email: dungkhi1@gmail.com

Ngày nhận bài: 19/10/2021

Ngày phản biên khoa hoc: 15/11/2021

Ngày duyệt băi: 19/12/2021

\section{OUTCOME OF BLOOD TRANSFUSION IN THALASSEMIA PATIENTS AT THAI NGUYEN CENTRAL HOSPITAL}

Objective: describle the clinical, laboratory and treatment outcome of blood transfusion in thalassemia patients at Thai Nguyen central hospital. Subjects and methods: Cross-sectional description of 53 patients were diagnosed with thalassemia at Thai Nguyen Central Hospital from June 2020 to September 2021. Result: $100 \%$ of patients have iron overload in which severe iron overload accounts for $67.9 \%$. Patients with splenomegaly and splenectomy accounted for $83 \%$, in which the rate of patients with grade I - II splenomegaly was the highest $(50.9 \%)$. The number of patients with hepatomegaly accounted for $74.4 \%$, dark skin accounted for $58.5 \%, 86,8 \%$ of patients with jaundice. The average $\mathrm{Hb}$ concentration at admission of the patients was: $65.91 \pm 12.33 \mathrm{~g} / \mathrm{l}$. $20.8 \%$ of patients had positive Coombs test results. The average interval between two consecutive blood transfusions of the study group patients was $4.82 \pm$ 1.26 weeks. The average volume of red blood cell infusion in 1 course of treatment was $477.36 \pm$ $179.36 \mathrm{ml}$. The average $\mathrm{Hb}$ concentration at discharge was $102 \pm 10.45 \mathrm{~g} / \mathrm{l}$. The average increase in $\mathrm{Hb}$ concentration was $36.83 \pm 13.84 \mathrm{~g} / \mathrm{l}$. The average need for blood transfusion/year is $251.58 \pm 113.05$ $\mathrm{ml} / \mathrm{kg} /$ year. The average weekly rate of decrease in $\mathrm{Hb}$ concentration was $5.25 \pm 3.54 \mathrm{~g} / \mathrm{l} /$ week. Conclusion: All patients have some clinical features such as: hepatomegaly, dark skin, jaundice, splenomegaly. The mean $\mathrm{Hb}$ concentration at admission was very low $(65.91 \pm 12.33 \mathrm{~g} / \mathrm{l}) .20 .8 \%$ of patients had a positive. Coombs test result. The need for blood transfusion of patients by year is very high $(251.58 \pm 113.05 \mathrm{ml} / \mathrm{kg} / \mathrm{year})$. The rate of patients with severe iron overload is $67.9 \%$, this subject needs to be actively chelated and monitored for complications.

Keywords: Thalassemia, hemoglobin, blood transfusion, iron overload

\section{I. ĐẶT VẤN ĐỀ}

Thalassemia là bệnh về huyết sắc tố (hemoglobin) có tính chất di truyền do thiếu sự 